The University of Maine

DigitalCommons@UMaine

Publications

Senator George J. Mitchell Center for Sustainability

Solutions

$11-2013$

\title{
Intergenerational Bargains: Negotiating our debts to the past and our obligations to the future
}

Mark W.Anderson

University of Maine

Follow this and additional works at: https://digitalcommons.library.umaine.edu/ mitchellcenter_pubs

Part of the Behavioral Economics Commons

\section{Repository Citation}

Anderson, Mark W., "Intergenerational Bargains: Negotiating our debts to the past and our obligations to the future" (2013).

Publications. 25.

https://digitalcommons.library.umaine.edu/mitchellcenter_pubs/25

This Article is brought to you for free and open access by DigitalCommons@UMaine. It has been accepted for inclusion in Publications by an authorized administrator of DigitalCommons@UMaine. For more information, please contact um.library.technical.services@maine.edu. 
Intergenerational Bargains: Negotiating our debts to the past and our obligations to the future

Mark W. Anderson

School of Economics, The University of Maine, Orono, Maine 
Abstract:

The question of intergenerational obligation can be framed in multiple ways. Here we use the idea of bargains to think about how those of us in the present relate to both the past and the future. To understand this approach assumptions behind the idea of intergenerational bargains are posited, three potential ontologies for intergenerational thinking are explored, and principles that might be applied to intergenerational obligations are considered. Finally, an ethic for intergenerational obligation is proposed. The idea of intergenerational bargains reveals common frameworks among futures studies, ecological economics, and sustainability science.

Key Words: Intergenerational issues; Rawls; equity and efficiency; constructed futures; social bequests; punctuated reciprocity; values; ecological economics; sustainability science.

Intergenerational Bargains: Negotiating our debts to the past and our obligations to the future 
"Depending on the choices we make now, future generations will either look back at our time with anger or with gratitude." [1]

\section{Introduction}

At any point in time, we sit, sometimes uncomfortably, between the past and the future. The discomfort of this position comes from our lack of a full understanding two things, how our past affects the trajectory of the future and how the people of the future will look back to our decisions, our legacy. Humans always sit at the crux of past decisions and future possibilities [2]. This locale can be understood as essentially the confluence of intergenerational bargains we participated in making and those we had no part in making but affect us in any event. The effective study of the future requires understanding the nature of these bargains in both a positive sense (in what ways does the future happen?) and a normative sense (what are our obligations to the past and the future and how can they be fulfilled?). This paper addresses both the positive and normative elements of intergenerational bargains and the problems posed by these bargains for understanding our relations with the people of the past and the future.

The idea of a bargain among generations is a departure from the typical ways that intergenerational relations are framed. These relations are usually discussed in terms of rights of future regenerations [3], justice toward future generations [4], or other ways the present expresses some duty toward the future. These frameworks are often only one step removed from neoclassical economics that accepts that the interests of the future are captured in the present's assessments of benefits and costs. In each of these intergenerational frameworks there is an asymmetry between those in the present and the future. The present is called upon to grant rights to, behave justly toward, ascribe values to, or otherwise acknowledge a duty toward the future. The idea of a bargain suggests 
a different frame, one where humans of past, present, and future have a similar standing, a more symmetrical relationship to one another.

Three broad areas of inquiry are necessary for understanding the idea of intergenerational bargains and how that idea differs from other approaches to intergenerational relations. First are the general principles for thinking about how generations relate to each other. The idea of intergenerational bargains entails acceptance that time is dimensional, the future is partially knowable, and the future is partially constructed by human actions. Dimensional time also requires us to understand that there may be ethical commitments among generations, even though some future individuals do not exist at present time.

Second, we must understand different ontologies of the path from past to present to future. Some see this path as teleology, an inexorable if uneven path to an end point, which is knowable. For others the path to the future is an evolutionary process, which is also knowable, where the mechanisms of natural selection work in social systems much as they do in the rest of nature. Related to both of these, but different in meaningful ways, is the idea of human progress. Here the future is seen as a partial construct from intentional human acts. While the future may not be completely created from human actions, there is at least some form of human agency that contributes to making the future "better," whatever we might mean that to be. In this last ontology, neither the end point or the process are knowable, rather they are conditional on the interaction of human behaviors and natural processes. The future is better, that is there is progress, only if humans make it so. Without agreement on the ontology of our study of the future we cannot agree on the epistemology or methodologies we should apply. This search for agreement on ontology, epistemology, and methodology is one that is necessary for emergent disciplines to be successful $[5 ; 6]$.

The third area of inquiry is that of the nature of intergenerational bargains, an issue that derives 
from this idea of progress. The idea of bargains presumes that humans have some partial control over the future, neither the end point nor the process is fixed, and this control can lead to "better" futures. Control then implies some sense of obligation to the future, although exactly what that obligation entails is contentious. Some analysts approach the question in a utilitarian framework such as neo-classical economists in benefit cost analysis. This could also include consideration of the problem as one of savings and investment or as a consideration of bequests and the legacy of the present to the future. Alternately, the issue is one of contracts among overlapping generations or a broader concern for the nature of justice. Or perhaps most recently, the question has become one of sustainability, somehow caring about those in the present and the future simultaneously. These obligations might lead to formal representation of future interests in present organs of government. The normative questions about the nature of our obligations to the future are, of course, complexified by limitations on our abilities to understand fully how the future is constructed from the past and present, an issue that has challenged futures research for decades.

Based on these three areas of inquiry, an ethic of intergenerational responsibility is proposed, an ethic that uses intergenerational bargains as an alternative conceptual framework. Inquiry into relations between generations caused some scholars to propose further disciplinary division [7]. The idea of intergenerational bargains is proposed here is a means to explore common conceptual ground between futures studies and the emerging disciplines of ecological economics [6] and of sustainability science [8].

Assumptions for thinking about intergenerational bargains

Dimensionality of time

The first important assumption here is that time is dimensional [9] and therefore roughly 
divisible into three distinctly different realms: the past, that which has happened, the present, which is being created jointly from realities of nature and the happenings of the past, and the future, that which is not yet but is possible. De Jouvenel [2] spoke of these realms as made up of facta, those things of the past that are fixed and knowable, if not fully known, and futura, those things yet to be realized. The future is made up of some combination of many futuribles, possibilities but not yet facts. This idea of futuribles anticipates Poli's notion of latents (although Poli does not use the futuribles idea in discussing latents). He says of them [10, p. 68], "Dispositions are the simplest case of latents, those features of reality embedded in it beneath its surface. Latents are real forces and structures that work below the threshold of visibility."

The (uncomfortable) present sits between facts past and futures possible. The early futurist Wayne Boucher pointed out that the present is a particularly challenging idea since, while we exist in the present, its elements are unknowable until it is past. He called this Boucher's paradox [9]. This paradox is at the heart of time as unidirectional, time's arrow [11]. From this present comes the future, as Polak [12, p. 1] argued, "His (the human) mental capacity to categorize and reorder reality within the self (present reality) and in relation to perceptions of the not self (the Other) enable him to be a citizen of two worlds: the present and the imagined. Out of this antithesis the future is born."

This same dialectic approach to the problem of time is not only at the heart of futures studies but also is central to the development of ecological economics. Georgescu-Roegen [13],

arguably the fountainhead of ecological economics, said "The texture of time consists not of abutting but overlapping durations (or specious presents, as they are often called). Moreover, they overlap in a dialectical not arithmomorphic structure." This resonates with Poli's [10, p. 72] idea that there is more than one present, that the present does not have a fixed duration, rather "is a multilayer structure..." This idea of overlapping presents is central to the ethics of intergenerational bargains. 
The important point here is that there is a reality to the past within which lies the possibilities of the future, but those possibilities do not have the same reality as the facts of the past. While this is not the only possible perspective on the nature of time, it is the one prevalent in much of futures research.

Knowing the Future, Constructing the Future

Given the dimensionality of time, it is not possible to know the future in the same sense that we can know the past. The future exists as a number of possibilities. Figure 1 (adapted from [9]) depicts time's arrow as cone moving from bottom to top, with A as the slice of events in the present. Some of the past is knowable, represented by the space within AGF in this figure, while some is unknown, for example event D, which is outside of our historical knowledge. The future can be forecast, imagined, predicted, projected, speculated on, or otherwise discussed, but this is always different from the knowledge of the past. The future does not exist in the same way. So in this ontology, the future is different from even event $\mathrm{D}$, which is unknown because it is outside the scope of human historical vision but is none the less a reality of the past. This is essentially part of a positivist ontology that does not demand humans to witness some element of reality for it to be real.

Implicit in the dimensionality of time is the understanding that the future is conditional, a product of past events, the laws of nature, and human intention. We can think of the future as partially constructed by human agency [2]. So our knowledge of the future is constrained by our less than full understanding of the ways the world works and of the present and future actions of human agents. Some of the future might be assigned a probability of occurrence, but there always will be "unforeseen developments [14]." So, in Figure 1, event E is such an unforeseen and probably unforeseeable development. It is unforeseeable because humans do not have a full understanding of the past (are unaware of event $\mathrm{D}$, for example) or because they do not fully know the dynamics of the 
processes through which the future unfolds. Like there is a limited realm of historical knowledge (AFG), there is a realm of future possibilities that can be anticipated (AJI). Fuller and Loogma [5] argue that this knowledge is a social construction. In a similar vein, in the realm of sustainability science there is growing acceptance that "scientific knowledge is socially constructed." [15, pp. 453-454]

Obligation to (or bargains with) non-existent humans

While the full extent to which the future is formed by human agency is arguable, clearly we try to shape the future into outcomes we desire. What are the political process and public policy development but intentional efforts to make the world into something more like one we find desirable to us? Spash [6, p. 45], again showing similarities between the foundations of futures studies and ecological economics, argues that "An objective reality exists independent of humans..." while "Humans create social reality..." Even unintentional behaviors affect the course of future change. Think of the act of deciding to have children or not, and if so, how many children to have or when to have them [3, pp.460-461]. Individually and collectively such decisions have a myriad of implications for the future, often unplanned by those making decisions.

The way we act or fail to act then is a normative concern. While the possibilities of the future are constrained by both the nature of reality and human decisions in the past (these define the futuribles), our contributions to the path of the future raise ethical questions. As we make decisions about our behaviors we cannot escape the reality that such behaviors impact the future. Do we therefore have some relationship to people to come, particularly to those who do not even now exist? Intergenerational bargains suggest that we should have ethical concerns for both the past and the future. 
Intergenerational Ontologies

Before thinking about the potential obligations of those in the present, it is important to specify in some detail the ontologies relevant to intergenerational questions. Ontological discussion is relevant to the idea of intergenerational bargains because, for those of us in the present to have an ethical obligation, it means that our actions must have predictable effects on the pathway from past to future. As Poli says [10,p. 75], “...elements of ontology should become part and parcel of the set of categorical tools any work futurist should have..." Ontological discussion should be part of ecological economics and sustainability science as well, since intergenerational issues are a shared concern among all three disciplines. At least three potential ontologies might be supposed, the third of which is inherent to the idea of intergenerational bargains.

Teleology

One vision of the pathways from past to future is represented in teleological perspectives like those of Theihard de Chardin [16]. In this view, time's arrow is at work but the end point is known, or at least knowable. To oversimplify the argument, the "complexification" of the planet is leading toward an end point, the Omega Point for de Chardin [16]. The process for this is the growth of the "noosphere," the sphere of human thought. For de Chardin the movement toward the end point is inexorable if uneven, so it is not a futurible in the way de Jouvenel [2] thought of this idea. While the development of the noosphere requires human agency, the possible futures are limited by movement toward the end point.

Theilhard de Chardin was both a theologian and a paleontologist, so while the process he described had some elements of evolutionary theory, the end point was clearly a reflection of his Christian cosmology. In this view, our obligations to the future are bound up in progress toward a 
known future. The future is known and the shape of its broad outlines is not conditional on intentional human agency. The Christian teleology of de Chardin is like the historical vision in Marxist-Leninist thought where historical processes inevitably were to lead to a known end point. This "historical materialism" in doctrine made forecasting in some ways easier because "the future is known" but more challenging because the known future could not be contradicted [17]. In this teleological view, our obligation to the future is limited to recognizing the inexorable path upon which we travel.

\section{Evolution}

In some important ways the growing application of evolutionary theory to social systems entails similar understanding that the conditionality of the future is limited. While the end point is not knowable, the process for achieving that end point is known, if not yet in all its details. The process is understood to be selection and transmission of traits through both biological and cultural processes [18]. In this vision, the future is the product of the evolutionary processes of natural selection working on both biology and culture. Whereas in teleology the end point is known, for the evolutionary theorist it is the process that is known or knowable, though this does not mean that there is yet consensus among evolutionary theorists over the details of that process. Witness the intense debate over multilevel selection theory [18]. Rather in this perspective evolution as a process is understood to be fundamental to describing the path to the future. Thus the task is to describe that process as an objective reality over which humans exert little or no control.

In both cases, teleology and evolution, human agency is limited and the future is not in a meaningful way conditional upon human actions; each expresses limits on human ability to create a more desirable future. To use de Jouvenel's language, futuribles are limited because of the fixity of 
either process or end point. Bromley [19, p. 235] argued that contemporary economics suffers from a similar flawed ontological presupposition, that there is a known process describing the path from present to future, freedom functioning through markets producing a 'spontaneous order." The assumption is that, "...if it is possible to obtain agreement on first principles of the process of provisioning, then the outcome of that process commands immediate and widespread consent."

For Bromley, the failures of the idea of spontaneous order are addressed through embrace of what he called a "constructed order." This is closely related to at one normative ontology of time's arrow, the idea of progress.

Progress and constructed futures

The third possibility is that humans have a significant impact on the path that the future will take, and the path is limited neither by pre-determined outcomes (teleology) or by partially fixed processes of change over time (evolution). This might be considered an ontology of progress, meaning that those in the present can make decisions affecting the path and direction of the future, albeit such future paths are constrained by the laws of nature and by past actions and events. This is a normative ontology in the sense that it allows humans to assert what is desirable and then act to effect change in that direction, to progress. Progress became in recent times a goal of public policy, particularly in the West during the post-World War II era. "The new idea of 'progress' come to provide a profoundly new dominating vision of the future. Now the future was expected to be indeed, was intended to be and was actively caused to be-different from and better than the present or the path.” [20a, p. 1-2]

In futures studies, backcasting [21] and other scenario-based tools [22] are examples of methodologies devised to help create more desirable futures. The future state that is desired is characterized and then the pathways from the present to that desirable outcome are developed 
through backcasting and other types of scenario-based analysis. As Quist and Vergragt said [21, p. 1030], “...backcasting is not necessarily only about how desirable futures can be attained, but also possibly analyzing the degree to which undesirable futures can be avoided or responded to."

It is in this understanding of our relationship to the future, the idea of progress that intergenerational bargains can occur. When humans in the present make decisions about desirable and undesirable futures, they affect others alive at that time and future humans who do not yet exist. Each decision in this context entails both intragenerational and intergenerational tradeoffs, many in the nature of bargains. In the language of sustainability science, the people of the future are stakeholders in the decision processes we engage in today [23].

For intragenerational tradeoffs, there are human institutions to manage how they are balanced. We have a variety of institutions to express and enforce rights --contracts, agreements, treaties, etc. All of these contribute to a system for managing bargains among people with various understandings about the principles for the conduct of such bargains, including justice, efficiency, reciprocity, legacy, and fairness. What is less well established are systems for managing bargains across generations, whether those are the bargains between individuals over time or collectively from one generation to the next. This is particularly important at the start of the $21{ }^{\text {st }}$ Century given our growing concern for sustainability, an idea which is at its core about intergenerational issues. [23]

\section{Principles of Intergenerational Obligation}

There are multiple ways we might think about our obligations to the future, particularly to those non-existent humans with whom we cannot directly bargain. How do we go about deciding whose interests should be counted and just what those interests are for any non-existent humans who deserve a voice and how do we accommodate those interests? There are several different constructs 
that address the normative questions of intergenerational bargains.

\section{Utilitarianism}

In neoclassical economics, the foundation of intergenerational obligation is utilitarianism. To think about this, imagine a barrel of oil in the ground. This is a non-renewable resource in the sense that we are using petroleum much faster than it could be reproduced by natural processes [24], so there are opportunity costs across generations in oil consumption. The barrel of oil I pump today will not be available to the next generation. Three broad options face us in the present given the legacy of oil resources and technology the past has left us. We can leave the oil in the ground and allow the future the choice of likewise leaving it untouched or pumping it. We can pump the oil, process and burn it, and consume the energy to enjoy our lives today (party on). Or we can pump the oil, process and burn it, and use the energy to invest in human or built capital that the future can use to enjoy their lives.

In utilitarian calculus the answer to the question of what to do is straightforward, at least in theory. Save, pump, consume, and invest the oil in the mix that maximizes the net utility over the relevant individuals. In the benefit/cost application, the task is to calculate the net present value of the various streams of costs and benefits that can be generated from the oil over time and use that mix that produces the maximum net present value [25]. If that allocation requires a change from the status quo and creates both winners and losers, that can be addressed through the compensation principle. The change is a Pareto improvement, in the words of welfare economics, as long as the winners compensate the losers for their losses and are themselves still better off than before the change. Since such compensation rarely if ever happens, the theory still asserts that the change is welfare improving as long as the compensation could have happened, a circumstance termed a 
potential Pareto improvement [25, p. 46].

At least four problems make this approach ethically tenuous for measuring the welfare effects of intergenerational bargains. First, it assumes that the distribution of benefits and costs of the different allocations of our barrel of oil are fixed over time. Yet we know that this distribution across the present generation would change with a different starting distribution of income and we know that preferences are not fixed in any meaningful sense. Norton et al. [26, p. 201] argued, “...over time, preferences may; be affected by human genetic evolution, education, technological change, the evolution of social systems, and the changing availability of environmental and other natural resources."

Second, benefit/cost analysis conflates the efficiency and equity criteria. Howarth and Norgaard [27, p. 3] explain, "While maximization of the present value criterion can be used to identify efficient allocations ...the criterion...cannot discriminate between efficient solutions resulting from alternative assignments of property rights." The result of this is a tacit acceptance of the status quo as equitable, including the allocation of right to decide to the present generation.

Third, even if we accepted the potential compensation principle as ethically legitimate in the present (Rawls [28, pp. 22-26] makes a compelling case that it is not), clearly compensation cannot occur over generations. Mishan [29, Chap. 69] called this the "potential Pareto improvement problem." Compensation of the future by the present is limited and compensation of the present by the future is impossible, the future does not yet exist.

The people of the future might well feel aggrieved were they to think that we justified our use of the barrel of oil for current consumption based on a utilitarian conclusion that we could have compensated them for the benefits they would have received had we left the oil in the ground, 
regardless of whether we did make such compensation. There is growing consensus among critics of neoclassical economics that such an approach, particularly as it is practiced in benefit/cost analysis, is not ethically tenable when intergenerational effects are considered. Hubacek and Mauerhofer [30, p. 416] argued in their critique of benefit/cost analysis, “...we can say that environmental degradation tends to impose the largest costs on those generations that are yet to be born. Future generations are disadvantaged with regards to present generations because they can inherit an impoverished quality of life, share a condition of structural weakness in have no voice and representation among the present generations, and so their interests are often neglected in present decisions and planning."

Finally, utilitarianism assumes that humans are the ultimate arbiter of what is right or good. It does not recognize that “...non-human inhabitants of Earth are morally considerable [6, p. 45].” An ideology that considers a broader ethic than one based on human preferences alone is premised on there being an "objective reality independent of humans" which we should acknowledge even though we may believe that knowledge of that realm is socially constructed.

\section{Savings and investment}

One variation in the utilitarian approach to intergenerational bargains is to focus on capacities rather than individual goods or resources. In thinking about sustainability, Solow [31, p. 133] argued that the idea “...doesn't require that any particular species or owl or any particular species of fish or any particular tract of land be preserved.” For him, questions about our particular barrel of barrel of oil and its use miss the point. Rather, our obligation to the future is one of leaving them the capacity to be "as well off as we are" and nothing more. In economic terminology, Solow saw capital in all its forms (human, natural, and technological) to be fungible across a wide range of uses. So we need not leave people of the future any specific mix of capital resources as long as the sum of our capital 
legacy to the future is such that they can be at least as well off as we are.

Essentially then the moral obligation to the future is one of savings and investment, the source of capital accumulation. As long as our savings and investments leave the future equally capable to us for creating wellbeing, then we have met the obligation. Of course, this leaves open the question of how much savings and investment this requires of us, but it does not require that we save a particular barrel of oil. Page [32 p. 595] suggested that the answer to the question of how much to save came from applying the golden rule of savings "...we should save for the future as much as we would have liked the past to have saved for us." This reinforces the idea of the future as stakeholders and of retrospective assessment, using our views of past decisions to intuit likely future perspectives on what we do today [23].

Solow's approach is now called the weak version of sustainability [33, pp. 310-316]. The distinction between weak and strong sustainability became important in the late $20^{\text {th }}$ Century dialog around questions of intergenerational relations [34].

\section{Sustainability --weak and strong}

In few areas of inquiry is the inter-temporal question so clear as it is in sustainability [33,

p. 304]. This question of obligation to the future, our role in intergenerational bargains, is central to the sustainability idea. Sustainability implies that we owe the future something in the same way we inherited things from the past. Solow's view that all forms of capital are interchangeable has been termed weak sustainability by critics skeptical that such fungibility will be meaningful to the future. These critics, starting with economist Herman Daly [35], see limits to the replacement of natural capital with artificial or human capital. For them, the stronger version of sustainability entails leaving the future certain aspects of nature undiminished if the future is to be left as well off as we 
are [34].

So it might be reasonable to think that investing the proceeds generated from the exploitation of non-renewable petroleum in development of energy efficiency or non-fossil fuel energy production technology might leave the future as well off as the present. Strong sustainability advocates would question exploiting hydropower potential of the Grand Canyon and using the electricity to develop artificial reality technology to re-create the experience of the Grand Canyon for future generations. The argument is that there are some forms of nature that are irreplaceable, no matter how much artificial or human capital has been accumulated. Norton [33, p. 307] said, "Strong sustainability...specifies limits on substitution, requiring that there must be limits on the replacement of natural assets with human-build ones." Elsewhere, Norton [33, p. 320] expands this notion: "There are some elements or processes in nature that are so important to the future that no generation is permitted to destroy them...If these essential resources are lost, people will be worse off than they would have been hand the items been protected - even if they are more wealthy than their ancestors."

Obviously no generation of 7 plus billion humans in the modern world will leave the future a natural world that is unchanged. What mix of human skill, technology, built environment, and natural landscape do we then owe future generations? Rawls [28] suggested that within the idea of justice we might find a way to answer that question.

Justice (Rawls)

Page's golden rule of savings evokes Rawls' concept of justice. Hubin [36], English [37], Page [32], Norton [38], Anderson et al. [23], and many others explored the application of the Rawlsian approach to justice to the question of allocation of resources across time. Justice became central to 
the idea of intergenerational bargains. Rawls proposed a thought experiment for considering the problem of justice, the idea of an original position where participants who would set the rules of justice by applying contract theory to the problem. Using the language I have used here, Rawls proposed that the bargain be made as if the participants did not know their interests. In the original position they are behind a "veil of ignorance" about their status. Importantly for thinking about intergenerational bargains, they are ignorant of what generation they belong to. Rawls said, "They must choose principles the consequences of which they are prepared to live with whatever generation they turn out to belong to.” [28, p. 137]

The Rawlsian approach solves the problem inherent in the idea of bargains between generations that the people of the present generations cannot contract with non-existent humans, future generations. Without Rawls the lack of reciprocity between humans of the present and the unborn, the idea of bargain is meaningless. How can you bargain with people who do not yet exist [30, p. 417 and 3, p $45 \mathrm{ff}$.]? If you are choosing the principles of justice across generations not knowing to which generation you belong, the reciprocity issue in this nonexistence issue becomes less constraining. The ethic is essentially an intergenerational Kantian one, we should treat the future as we would have had ourselves treated by the past. The way to know this has been accomplished is by imagining the result from Rawls' original position behind the veil of ignorance. In a sense the Rawlsian approach softens the differences between past, present, and future allowing for intergenerational bargains to be made.

What intergenerational bargains would you agree to, were you ignorant of your generation? Hubin [36, p. 83] concludes from applying a Rawlsian framework, “...whatever duties we may have with regard to future generations, we have ... a duty of justice to preserve the environment and to conserve natural resources for the benefit of future generations provide that do so does not involve us in an injustice to members of our own generation.” 


\section{Reciprocity/contract}

Others have adopted approaches very close to this Rawlsian construct. For Padilla [39, p.75] sustainable development is a moral agreement between generations that rejects the idea that all rights reside in the present, the idea implicit in benefit/cost analysis discussed above. He argued that, “...present actions should be bounded within some limits. It would be more appropriate...to assume the (sic) sustainable development as an implicit moral agreement moral agreement between generations." The obvious first question is the root of such moral obligation beyond the mere assertion that it is illegitimate that all rights reside only in the present. This stance must also be a rejection of the "... reciprocity theory of rights (that) holds that we have duties only toward those who are in a position to reciprocate by respecting our rights [40, p. 95].” Hubin [36, p. 71] called this, “...the rather sticky problem of how person who do not share a common period of life could acquire obligations to one another. This relationship could not result from of relationship of mutual benefit (reciprocity)...”

Ball [40, p. 104] proposed that the idea of punctuated reciprocity should be applied. "As with any inheritance, we did nothing to earn it, nor can we repay our ancestors. But we can at least augment it, and pass it on to future generations." He goes on to suggest that time be thought of using a river metaphor. Those in the future are "downstream" on the river of time and therefore should have rights like riparian rights downstream on a real river [40, pp. 107-108]. Ball's idea is similar to that of Bromley's critique of the spontaneous order in contemporary economics. Bromley argued that we replace the spontaneous order idea with "environmental regency" in an "overlapping generations model.” In this, “...those in the present, the regents, pledge collateral against the possibility that we may, in a moment of weakness, violate the interests of the future. We do this by setting aside natural and constructed assets. [19, p. 237]." For him, these "social bequests" will constitute our legacy. 
Future Representation in Organs of Governance

Another prominent line of thinking about relations between present and future is the idea of modifying democratic institutions to provide a means of representing future generations. [41] While Rawls' thought experiment was never intended to be an actual assembly convened "behind a veil of ignorance" to establish rules of justice, several innovations have been proposed to provide literal representation for the future in present governance mechanisms.

Dobson [42] suggested creation of seats in legislative bodies for representation of the future. Ekeli [43] called Dobson's approach a "restricted franchise model” because voting for futures representatives was limited to groups assumed to function as a proxy for future generations, specifically the "environmental sustainability lobby." Ekeli advocated a broader franchise, recognizing that concern for the future is probably not limited to environmental interests. Rather his approach was based on principles of "deliberative democracy." [43, pp. 433-441]

Practical manifestations of these ides of future representation appear in international governance dialog as well. In 1997 UNESCO adopted a Declaration on the Responsibilities of Present Generations Towards Future Generations [44]. Gopel, writing for World Future Council advocated Obudspersons for the future [45]. These ombudspersons were modeled on recent experience, largely in legislative assemblies in New Zealand, Hungary, and Israel.

Earlier than these proposals, Dator [46, pp. 64-65] suggested, based on his experience in the United States, that the judicial branches of government might be more appropriate homes for futures concerns. He notes that, "Because 'the future' neither votes nor has a PAC, no politician from a reasonably contested district can afford to think about the interests of the future except as they; are embodied in the interests of the present...compared to other political and economic decision makers 
in the U.S., judges tend to have a longer 'natural' time horizon. Relatively freed from current pressures, they; can think about longer consequences and interests."

Earlier still was the impact of futures research in the U.S. congress starting in the early 1970s [47]. That saw the creation of a Congressional Office of Technology Assessment (OTA), a Futures Research Group within the Congressional Research Service of the Library of Congress, and a Congressional Clearinghouse on the Future. Congressional committee rules were changed to dictate that each committee "... shall on a continuing basis undertake futures research and forecasting on matters within the jurisdiction of that committee [47, p. 288]. Over the years following each of these provisions and offices was eliminated, the OTA lasting longest until its elimination in 1995. An interesting empirical question is why; when concerns for future generations are institutionalized in government they have mostly failed to persist. Clearly whatever principles of intergenerational relations we embrace, including the idea of bargains, the ethic will only be as effective as its means of implementation.

Perhaps at the core of these failures to establish permanent representation of future interests in organs of government is a certain distrust that the future will hold up its end of the bargain.

What should we expect from the future?

Reciprocity, which is inherent in the idea of intergenerational bargains, creates particular problems when thinking about our obligations to future humans if we so choose to extend the moral argument. Were we to work to construct a future life based on a sense of our obligations, however those obligations are understood, what should we expect in return from the future? What is the reciprocal expectation for the future in this bargain? Return to the barrel of oil we considered above. 
Imagine we in the present determined that crude oil is so important to creating human wellbeing in the future that we reduce consumption dramatically to extend the number of generations for which oil is available. One obvious problem is we have no way of assuring that the next generation or the one after that will adopt a policy that also embraces the same ethic. Those people could decide to maximize their enjoyment of the fruits of oil consumption in their generation by consuming the oil forgone by our generation and more. Since we cannot enforce such conservation across generations and reciprocity is not assured, the idea of bargains among generations is weakened. How do we learn to trust that the future will participate in the same vision we have of the path to the future? How do we deal with the real possibility that future generations will not be good stewards of our bequest to them?

Land trusts and other environmental groups that "protect" lands for the future are examples in current conservation where this issue is very concrete. Imagine that I grant an easement for a perpetual prohibition of any more development of a parcel of land to a land trust, The Nature Conservancy, or some other group. I am trusting in several aspects of the future when I do this. I trust that future boards of directors of the easement holder organization will respect my wishes and enforce the easement in the manner I desired. Will their values and world view (ideology) be the same as mine? I trust the legal system will also enforce such restrictions when the entrusted group tries to maintain the intent of the easement through legal action. I trust that future public policy will not deem that the public interest supersedes my private ones in establishing the easement.

We can find examples where people of the future have not felt compelled to accept all of the conditions the past has tried to impose on them. In one famous example, the substantial art collection of John G. Johnson was left to the City of Philadelphia subject to conditions on where the art would be displayed, conditions that the courts eventually overturned [48]. Essentially Johnson's judgment 
about how his values would best be met in the future were overridden by practicalities once that future arrived. The bargain was not honored.

So the temporal dimensions of intergenerational bargains make them risky for those of us in the present. Even if we agree among ourselves in the present what our obligations to the future are and we sacrifice increases in present wellbeing to assure that the future's needs are met, we can have no assurances that some future generation will reciprocate and treat its future similarly. If we cannot trust the future to follow our lead and address the needs of its future, does that obviate our need to enter into the appropriate intergenerational bargain?

\section{Conclusions}

The idea of a bargain is that two consenting and equally capable parties agree on what they will do for each other. Sometimes bargains include how the participants will enforce that agreement and what penalties will be assessed if the bargain is not kept. But bargains often entail some trust relationship, they are more than mere formal contracts. They can be consummated with a handshake or a nod and the exact nature of the reciprocity may be vague or even unstated. This is the particular nature of intergenerational bargains.

Bargains are also a fundamentally different way of approaching intergenerational relations. Given the ontology of time discussed above, bargaining cannot reject the difference between past, present, and future. But it does treat these differently than in a rights, justice, or utilitarian framework of intergenerational relations. Granting rights to future generations, exercising regency on the future's behalf, or other approaches to this problem suggest acceptance of power in the present, which we might call presentism. The presentism emphasizes the difference between Us (the present) and the Other (past and future) [2]. Returning to the dialectic of Polak and of Gerogescu-Roegen 
discussed above, intergenerational bargains emphasizes what generations have in common, not what makes them different. Rawls' veil of ignorance is the apt thought experiment for helping us think about what our role might be in such a realm while still recognizing that in the end we cannot ignore time's arrow.

The motivation for what we do with the past and the future often comes from some ethical motivation. This may be reciprocal in the sense that Ball talks of "punctuated reciprocity." We were treated well by the previous generations and so future generations deserve as much from us. Or it may be a personal commitment to a familial line or some other similar relationship. Aldo Leopold [49] argued that humans had, over time, expanded the bounds of the group to which we felt an ethical responsibility - family, tribe, nation, etc. - and that we needed to expand that circle to include the natural world, what he called the Land. It is clear that there is a similar expansion that includes future humans in that circle of who deserves our ethical recognition. As discussed above, in this ideology humans are not the only part of the Earth that are "morally considerable [6]."

Following in the Leopold tradition, Norton [33, p. 338] expanded this community-based approach and treated community as a basis for thinking about our relations with the future. He said, "...I have recommended that some non-economic obligations to the future be considered communal goods. We have these obligations because, as members of a community and culture, we benefit from the sacrifices and investment made by members of prior generations."

Of course, because of the lack of potential for direct reciprocity, we do not compensate the past for this bequest to us, nor will we be compensated for our bequest to the future. We will not even know how the future deals with their legacy from us. Presumably Johnson does no know that the City of Philadelphia failed to honor the terms of his will. So this is the ultimate trust relationship. In doing 
the right thing by the future we must trust that those are benefited are grateful and in turn also do the right thing for humans after them.

Given this necessary trust relationship, we work as well then to shape the values of the future in order to protect our interests in the bargains. This is part of the way the future is socially constructed [5]. Much like Krutilla [50] suggested that providing certain nature-based experiences in the present could generate demand for wilderness experiences in the future, our treatment of the future today could shape the ethics of the future. Norton et al. [26, p. 205] reaffirmed this idea, also using wilderness as an example, “...the decision to invest in protecting a wilderness area carries with it a commitment, or at least a desire, to influence the future to continue to value wild places and naturally evolved species.” As Bromley said [19, p. 239], "We do not leave the values of our children to chance and there seems scant reason to suppose that we should do so with respect to future generations."

So central to our legacy are the values [51] that we impart to the future. Returning again to Norton [33, p. 339], “...deciding how we should protect options (for the future) that we decide are important - the ideas, values, and institutions we develop to support our value choices - will inevitably shape future decisions and choices."

Through our actions we become role models that help assure the maintenance of punctuated reciprocity for the community of those humans past, present, and future. Perhaps the first step is to reflect on the legacy we inherited, including both parts for which we are grateful and those we regret. From that we can imagine the future [12] and how we would like those who populate it to reflect on our bequest. Will they see us as having been good community stewards who upheld the trust of what we were given in the manner in which we passed it on. Then we might avoid Ball's fear that, "We are probably the worst ancestors than any people could possibly have" [40, p. 91]. 


\section{Acknowledgements:}

This research was conducted as part of Maine's Sustainability Solutions Initiative, supported by National Science Foundation award EPS-0904155 to Maine EPSCoR at the University of Maine. Thanks are due to Michelle Johnson for insightful comments on an earlier draft of this paper and to Mario Teisl for numerous conversations about these topics. Two anonymous reviewers provided excellent comments that helped improve the argument made here. 


\section{References}

[1] New Economics Foundation, Happy Planet Index 2.0, London, 2009.

http://www.neweconomics.org/sites/neweconomics.org/files/The_Happy_Planet_Index_2.0_1.pdf, accessed March 26, 2013.

[2] B. de Jouvenel, The Art of Conjecture, Basic Books, New York, 1967.

[3] A. Gosseries, On Future Generations' Future Rights, Journal of Political Philosophy, 77(2008), 446-474.

[4] J. Thompson, Intergenerational Justice: Rights and Responsibilities in an Intergenerational Polity, Routledge, New York, 2009.

[5] T. Fuller and K. Loogma, Constructing futures: A social constructionist perspective on foresight metholdology, Futures, 41 (2009), 71-79.

[6] C. Spash, New foundations for ecological economics, Ecological Economics, 77 (2012), 36

47.

[7] J.S. del Pino, Future studies and future generations, Futures, 39 (2007), 113-116,

[8] R. Kates, et al., Sustainability Science, Science, 292 (2001), 641-642.

[9] M.W. Anderson, Time: How Do Futurists Perceive It?, World Future Soc. Bul. XI,3 (1977) $15-21$.

[10] R. Poli, Steps Toward an Explicit Ontology of the Future, Journal of Futures Studies, 16(1), (2011), 67-78.

[11] Blum, H. F. Time's Arrow and Evolution ( $3^{\text {rd }}$ ed.), Princeton, Princeton University Press, 1968.

[12] F. Polak, The Image of the Future, (E. Boulding, trans.), Amsterdam, Elsevier, 1973.

[13] N. Georgescu-Roegen, The Entropy Law and the Economic Process, Cambridge, Harvard University Press, 1971.

[14] T. J. Gordon, The Nature of Unforeseen Developments, in W. I. Boucher (ed), The Study of the Future: An Agenda for Research, Washington, D.C., The National Science Foundation, 1977, pp. 38-42.

[15] L. van Kerkoff and L. Lebel, Linking Knowledge and Action for Sustainable Development, Annual Review of Environment and Resources, 31 (2006), 445-477.

[16] P. Theilhard de Chardin, The Phenomenon of Man, New York, Harper \& Row, 1965. 
[17] W. I. Boucher, Forecasting When the Future is Known, in W.I. Boucher (ed), The Study of the Future: An Agenda for Research, Washington, D.C., The National Science Foundation, 1977, pp. 137-163.

[18] D.S. Wilson and E.O. Wilson, Rethinking the Theoretical Foundation of Sociobiology, The Quarterly Review of Biology, 82 (2007), 327-348.

[19] D. Bromley, Searching for sustainability: The poverty of spontaneous order, Ecological Economics, 24 (1998), 231-240.

[20] T. Kim and J. Dator, Future Generations - They Are Our Consience, in T. Kim and J. Dator (eds.), Co-Creating a Public Policy for Future Generations, Westport, CT, Praeger.

[21] J. Quist and P. Vergragt, Past and future of backcasting: The shift to stakeholder participation and a proposal for a methodological framework, Futures, 38 (2006) 1027-1045.

[22] R.J. Swart, P. Raskin, and J. Robinson, The problem of the future: sustainability science and scenario analysis, Global Environmental Change, 14 (2004), 137-146.

[23], M.W. Anderson, M. Teisl, and C.N. Noblet. Giving voice to the future in sustainability: Retrospective assessment to learn prospective stakeholder engagement, Ecological Economics, 84 (2012), 1-6.

[24] J. Dukes, Burning Buried Sunshine: Human Consumption of Ancient Solar Energy, Climatic Change, 61 (2003), 31-44.

[25] R. Just, D. Hueth, and A. Schmitz, Applied Welfare Economics and Public Policy, Englewood Cliffs, NJ, Prentice-Hall, 1982.

[26] B. Norton, R. Costanza, and R. Bishop, The evolution of preferences: Why 'sovereign' preferences may not lead to sustainable policies and what to do about it, Ecological Economics, 24 (1998), 193-211.

[27] R. Howard and R. Norgaard, Intergenerational Resource Rights, Efficiency, and Social Optimality, Land Economics, 66 (1), (1990), 1-11.

[28] J. Rawls, A Theory of Justice, Cambridge, Belknap Press of Harvard University Press, 1971.

[29] E.J.Mishan, Normative Economics, New York, Oxford University Press, 1981.

[30] K. Hubacek anv V. Mauerhofer, Future generations: Economic, legal and institutional aspects, Futures, 40 (2008), 413-423.

[31] R. Solow, Sustainability: An Economist's Perspective, in R. Stavins (ed.), Economics of the 
Environment, $4^{\text {th }}$ Ed. New York, W.W. Norton, 2000.

[32] T. Page, On the Problem of Achieving Efficiency and Equity, Intergenerationally, Land Economics, 73 (1997), 580-596.

[33] B. Norton, Sustainability: A Philosophy of Adaptive Ecosystem Management, Chicago, University of Chicago Press, 2005.

[34] S.C. Hackett, Weak vs. Strong Sustainability Debate, in I. Spellerberg et al. (eds.), Berkshire Encyclopedia of Sustainability, Vol. 6: Measurements, Indicators, and Research Methods for Sustainability, Great Barrington, MA, Berkshire Publishing.

[35] H.E. Daly, Economics as a Life Science, Journal of Political Economy, 76 (1968), 392-406.

[36] D.C. Hubin, Justice and Future Generations, Philosophy and Public Affairs, 6 (1), (1976), 70-83.

[37] J. English, Justice Between Generations, Philosophical Studies, 31(2), (1997), 91-104

[38] B. Norton, Intergenerational Equity and Environmental Decisions: A Model Using Rawls' Veil of Ignorance, Ecological Economics, 1 (1989), 137-159.

[39] E. Padilla, Intergenerational equity and sustainability, Ecological Economics, 41 (2002), 69 83.

[40] T. Ball, New Ethics for Old? Or, How (Not) to Think About Future Generations, Environmental Politics, 10(1) (2001), 89-110.

[41] T. Kim and J. Dator (eds.), Co-Creating a Public Philosophy for Future Generations, Praeger, Westport, CT, 1999.

[42] A. Dobson, Representative Democracy and the Environment, in W. Lafferty and J. Meadowcraft (eds.), Democracy and the Environment, Elgar, Cheltenham, 1996.

[43] K. S. Ekeli, Giving a Voice to Posterity - Deliberative Democracy and Representation of Future People, Journal of Agricultural and Environmental Ethics, 18 (2005), 429-450.

[44] UNESCO, Declaration on the Responsibilities of the Present Generations Towards Future Generations, United Nations Educational, Scientific and Cultural Organization, Paris, 1997

[45] M. Gopel, Ombudspersons for Future Generations as Sustainability Implementation Units, Stakeholder Form, Paris, http://www.stakeholderforum.org/fileadmin/files/SDG\%204\%20Ombudspersons\% 20for\%20Future\%20Generations\%20Thinkpiece.pdf accessed August 20, 2013.

[46] J. Dator, The Dancing Judicial Zen Masters: How Many Judges Does It Take to See the Future?, Technological Forecasting and Social Change, 46 (1994), 59-70. 
[47] M. Anderson, The Institutionalization of Futures Research in the U.S. Congress, Technological Forecasting and Social Change, 11 (1978), 287-296.

[48] G. St. John, John G. Johnson: Giant of the Philadelphia Bar, The Philadelphia Lawyer, 69 (Winter 2007), 3 pages.

http://www.philadelphiabar.org/page/TPLWinter07Johnson?appNum=2 (Accessed July 1, 2013).

[49] A. Leopold, A Sand County Almanac, New York, Oxford University Press, 1949.

[50] J. Krutilla, Conservation Reconsidered, American Economic Review, 57 (1967), 777-786.

[51] M.W. Anderson and M. Teisl, Values, in Berkshire Encyclopedia of Sustainability, Vol. X, The Future of Sustainability, Great Barrington, MA, Berkshire Publishing, 211-218. 
Figure

Figure 1. Relationship of Past to Future Implict in Unicimensional Time (adapted from [3])

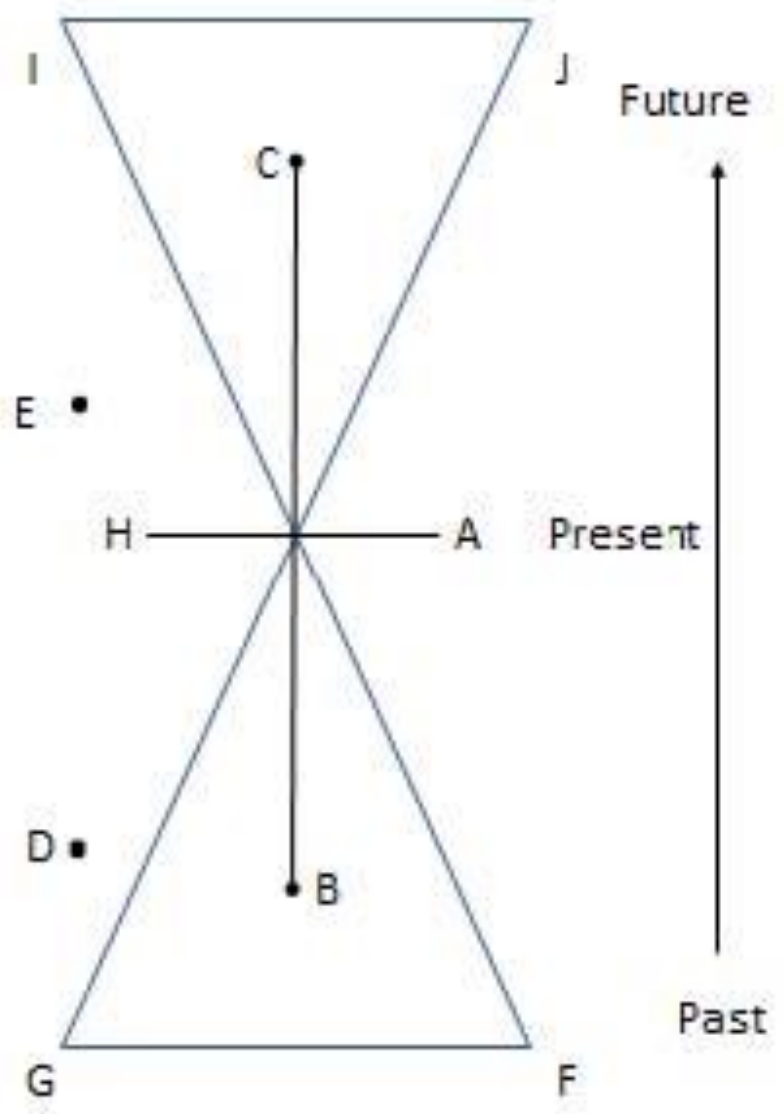

